\title{
I-2-1 中間広筋単独皮下断裂に伴う大腿前方笳区画症候群の一症例
}

\author{
国立佐賀病院整形外科 \\ ○井上博文（いのうえひろふみ）、神代敏之、乗松崇裕 \\ 北野整形外科 北野克顕
}

【はじめに】中間広筋の皮下断裂に伴う大腿前方筋区画症候群の一例を経験したので報告する 【症例および経過】17才、男子高校生。バスケットボールの試合中、軸足の大腿部に相手の 䐂があたり受傷した。直後より起立不能となり近医受診。大腿部の腫脹が強く、受傷後 3 時 間で紹介来院した。

【経過】大腿周径差が最大 $4 \mathrm{~cm}$ で、膝関節可動域は 0 ～ $20^{\circ}$ と制限されていたが、神経症状 はなく、膝窩・足背動脈とも触知良好であった。受傷後 24 時間で筋区画内圧が $100 \mathrm{mmHg}$ を越えたため筋膜切開を行なった。中間広筋の部分断裂と同部に多量の血腫を確認した。 【考察】スポーツ障害としての大腿部前方筋区画症候群の報告は散見されるが、中間広筋の単 独皮下断裂に伴うものは極めて少ない。

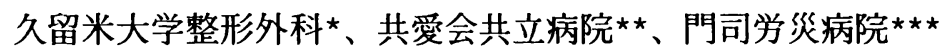

○菌田恭輔（そのだきょうすけ）、永田見生、井上明生*、有吉 護、

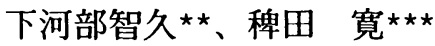

【目的1】水泳は脊椎や下肢関節に体重負荷をかけることなく行えるため、中高年に適し た運動であると思われるが、時に水泳が原因と考えられる障害が報告されている。そこで 中高年者の水泳の実施状況と水泳障害発生の実態を調査し、その要因について検討した。 【方法】北九州のスイミングクラブのフリーコースで水泳をしている 7 施設546名にアンケー 卜調査を行なった。

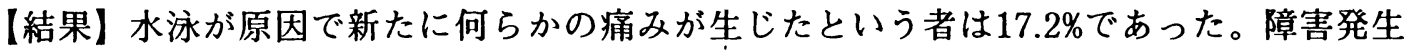
部位は肩、腰、膝に多かった。基礎に変形性疾患などを有する者の障害発生率は $26.9 \%$ 、 ない者6.5\%に比べ有意に高かった。水泳障害がある群とない群では、泳ぐ種目、練習量で は差を認めなかったが、ある群では、泳ぎ方に問題があるように思われた。 


\title{
I-2-3 フェンシング選手に生じた坐骨疲労骨折の2例
}

\author{
鳥取県立中央病院 整形外科
}

○山本哲章（やまもとのりあき），䲐俊朗，山本清司，岸隆広

【目的】フェンシングによる坐骨の疲労骨折は稀である。今回我々はフェンシングにより惹起 された坐骨の疲労骨折を2例経験したので報告する。【症例1】高校2年生男子、高校よりフェン シングを始める。開脚時右殿部痛を自覚、疼痛徐々に増悪するため受診。利き腕側の右坐骨結 節部に骨折線を認める。競技活動の中止を指示するがまもれず疼痛が持続している。【症例2】 高校 2 年生男子、高校よりフェンシングを始める。開脚時左殿部痛を自覚、半年後疼痛のため走 れなくなり受診。利き腕側の左坐骨上枝と寛骨臼下縁の間に骨折線を認める。1ヶ月間の競技活 動中止と、股関節内転筋群およびハムストリングのストレッチにて競技活動に復帰している。

【考察】フェンシング特有の開脚フォームと坐骨枝に付着するハムストリング、股関節内転筋 群、外旋筋群の緊張により坐骨にストレスを生じ坐骨枝の疲労骨折を生じたと考える。

\section{I-2-4 ウエイトリフターに発症した両側腱板完全断裂の 2 症例}

福岡大学医学部整形外科学教室

○舌間崇士（したまたかし）、柴田陽三、緑川孝二.

【目的】ウエイトリフターに発症した両側腱板完全断裂の 2 例を経験した。【症例】症例 1 は 38歳（初診時）男性、ウエイトリフティング開始後3年で左肩痛発症、5年で右肩痛発症、放 置していたが平成3年当科初診し、両側腱板完全断裂の診断で腱板修復術施行した。右術後7.5 年、左術後6.5年で現在疼痛なく活動している。症例2は23歳男性、ウエイトリフティング開 始後 3 年で左肩痛、 4 年で軽外傷後右肩痛増強、平成 11 年当科初診し、両肩腱板完全断裂に診 断にて腱板修復術を施行した。右術後 3 力月、左術後 1 力で現在リハビリテーション中である。

【考察】腱板完全断裂は比較的よく見られる疾患であるが、発症年齢においては、発生要因と して腱板の退行変性が基盤にあるが故に一般に高齢者に好発する。しかし、今回の2症例は38 歳と23歳と若かった。また、ウエイトリフティングにおいては、日常生活や通常のスポーツで はかかりえないような強大な機械的ストレスが加わるためか両側に発症していた。 